\title{
Suitability of Coconut Shell Concrete for Precast Cool Wall Panel-A Review
}

\author{
Shahiron Shahidan ${ }^{1, a}$, Alif Syazani Leman ${ }^{2}$, Mohamad Syamir Senin ${ }^{3}$, Nurul Izzati Raihan Ramzi Hannan ${ }^{4}$ \\ 1,2,3,4 University Tun Hussein Onn Malaysia 86400 Batu Pahat, Johor, Malaysia
}

\begin{abstract}
The cost for producing concrete has been increasing steadily. Therefore, the demand for using agricultural waste as a replacement or admixture inside concrete is also increasing gradually. Many researchers are doing research on agricultural waste such as palm oil, corn cobs, rice husks and coconut shells. Agricultural waste is increasingly being utilized in cement, concrete and other construction materials and provides numerous indirect benefits such as reduction in land fill cost, saving energy and protecting the environment from possible pollution. The aim is to produce concrete with improved properties at a lower cost and to maintain environmental sustainability. In this review paper, the suitability of coconut shell for concrete cool wall panels will be the main focus. Coconut shells can be used as aggregates in concrete. The characteristic properties of coconut shell concrete such as workability, bulk density, compressive strength, flexural tensile, water absorption and thermal performance were reviewed in this paper. This paper attempts to answer whether coconut shell is suitable to be used in concrete to produce a concrete cool wall panel in order to reduce heat transfer inside a building.
\end{abstract}

\section{Introduction}

The most critical issue in environment protection and natural resource conservation is waste management [1][2]. Changes in environment and an increase in population are the main causes of the many processes of deterioration which have altered the ecosystem of our planet, including the generation of municipal solid waste (MFS) [3][4]. Therefore, there is a need to reuse waste to create a greener and healthier place on earth. The usage of agricultural waste will be emphasised in this research. Being renewable, low-cost, lightweight, having high specific strength and stiffness have made agricultural waste ideal for use as construction materials [5]. Coconut shell, oil palm shell, oil palm clinker, corncob ash, and rice husk ash are all agricultural by-products. Although some of these materials can be used as animal feed or fuel in biomass power plants or boilers of various industrial sectors to produce steam, a lot of these materials are still disposed off into landfills or burnt. This leads to serious environmental problems [6][7].

Coconut is grown in more than 90 countries in an area of 14.231 million hectares with a total production in terms of copra equivalent of 11.04 million (mt). Indonesia $(25.63 \%)$, Philippines $(23.91 \%)$, and India $(19.20 \%)$ are the major coconut-producing countries in the world [8]. Due to the increased dumping of agricultural waste, coconut was used in concrete in this research as a filler in a precast wall.

According to Kardooni et al. [9], as the most visited country in Southeast Asia, the climate in Malaysia shows

\footnotetext{
a Corresponding author: shahironshahidan@gmail.com
}

that the temperature increased by $0.18{ }^{\circ} \mathrm{C}$ per decade for over 40 years. From the data received, it is crucial to ensure that the people of Malaysia live in a cool house as the temperature has risen. It happens because of convective heat transfer from internal room surface which has a major effect on the thermal comfort, air movement and heating and cooling loads for the room [10]. Recent studies have shown the convective heat transfer varies from surface to surface in buildings, as well as with time, in response to local air flow patterns. The calculation of convection coefficients must correspond to local flow conditions in a dynamic fashion in order to accurately capture this effect [11][12].

Therefore, in order to achieve a comfortable environment, this research will emphasize on utilizing coconut shell fillers to form composite materials in constructing a wall panel that is strong and can be used to replace conventional walls. Doing so will reduce the cost of construction and make the room cooler. It will also help to reduce agricultural waste and make the world more sustainable.

\section{Coconut Shell Concrete}

Coconut shell is one of the solid disposal wastes from agricultural activities. The use of coconut shells as one of the composite materials in the production of concrete was driven by the problem caused by the disposal of solid waste. According to Gunasekaran et. al [13], coconut shells represent more than $60 \%$ of domestic waste volume. Coconut shells present serious disposal problems 
for local environments. However, these wastes can be used as potential material or replacement material in the construction industry.

Previous research by Osei et. al. [14] stated that coconut shells are by-products of coconut oil production. Coconut shells are used in the production of activated carbon due to its hardness and high carbon content. Besides, Kambli et al. [15] mentioned that coconut shells are potential candidates for the development of new composite material in concrete mix design because of their high strength and modulus properties.

In addition, the use of coconut shells in concrete production will give more benefits compared to conventional materials. If coconut shells are used for structural applications, it would not only be advantageous towards the environment, but also towards low-income families, especially in the surrounding areas of coconut plantations [16]. Figure 1.0 shows an example of coconut shells.

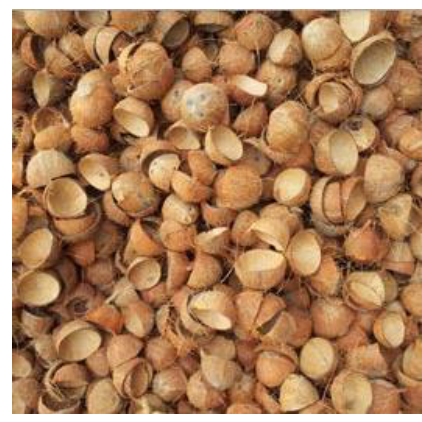

Figure 1.0 : Example Of Coconut Shells[12]

\section{Properties Of Concrete}

To utilize agricultural waste such as coconut shells as an admixture or a replacement in concrete mixtures.

\subsection{Fresh Concrete}

The tests were all conducted under the standard procedure of ASTM that include workability and bulk density.

\subsubsection{Workability}

Yerramala et al. [17] in his study examined the slump value between control concrete and coconut shell concrete that have a range between 20 to $26 \mathrm{~mm}$. However, the slump value gradually decreased with the increase of coconut shell content inside the concrete. Apart from that, Gunasekaran et al. [13] concluded that coconut shell concrete has excellent workability compared to conventional concrete because of the smooth surface on one side of the shells as well as the size of coconut shells used. This is also because of the low water-cement ratio. Besides that, Rahman et al. [18] also found that the workability of coconut shell concrete is much better compared to control concrete. The reason is that the coconut shells bind better with concrete. D. Osei [14] in his research provided that the workability of true slump obtained with coconut shell added to concrete. It seems that all researches show that the workability of coconut shell concrete is far away better than normal concrete. True workability means that it is easier to handle the concrete during the mixing process.

\subsubsection{Bulk Density}

Pooja et al. [19] found that concrete added with coconut shells has a lower density. The 28-day air dry density was less than $2000 \mathrm{~kg} / \mathrm{m} 3$ and it was within the range of structural lightweight concrete. The research is proven as M. Kaur et al. [20] concluded that coconut shells suffice as a lightweight aggregate in concrete. The replacement of coarse aggregate with coconut shells has made the concrete lightweight because the coconut shell density itself is lower than the density of coarse aggregates. Ahmeed et al. [21] found that at $30 \%$ of replacement, the density of coconut shell concrete is $2240 \mathrm{~kg} / \mathrm{m} 3$. It also stated that the density of the concrete containing coconut shells decreases as the percentage of replacement increases. Apart from that Shafigh et al. [22] stated that the replacement of coarse aggregates with coconut shells can produce a lightweight concrete since it shows a value that is less than normal concrete. Besides that, a study conducted by Ganiron et al. [23] shows that a value of $1213.59 \mathrm{~kg} / \mathrm{m} 3$ was obtained when coconut shells were used to replace coarse aggregate. The value that obtained by the researcher was for construction purposes such as wall panels and partitions.

\subsection{Hardened Concrete}

Hardened concrete was also tested under the standard procedure of ASTM that includes compressive strength, flexural tensile and moisture content.

\subsubsection{Compressive Strength}

According to Gunasekaran et al. [24] the compressive strength of the concrete containing coconut shell as a coarse aggregate replacement depends on its matrix and the particle tensile strength of the aggregate. The statement was supported when Kumar et al. [25] found that the maximum compressive strength was attained at $0 \%$ of replacement and the minimum strength was obtained at $10 \%$ replacement. The result shows that the strength decreases as the percentage of replacement increases due to the bond between them. Apart from that, Olan et al. [26] also studied the substitution of coarse aggregate with coconut shell at the gradation of $0 \%, 25 \%$, $50 \%, 75 \%$ and $100 \%$. The result shows the same pattern as the findings of the previous researcher that is the compressive strength also decreases as the replacement percentage increases. Besides that, B. Rajeevan et. al [27] reviewed the strength of concrete replaced with $20 \%$, 
$30 \%, 40 \%, 50 \%$ and $100 \%$ also showed a decrease pattern. Meanwhile, D. Ahlawat et. al. [28] have found that as the content of coconut shell increases, the surface area also increases and required more cement for proper bonding. It shows that since the cement content is constant, there is no extra bonding and thus the strength is reduced. However, there are certain percentages of replacement that can increase concrete strength. From the review, the range of replacement must be under $10 \%$ so that the concrete containing coconut shells has a higher strength.

\subsubsection{Flexural Strength}

Based on Jaya et al. [29], it was found that the flexural tensile strength value obtained was $6.52 \mathrm{MPa}$. This is due to the size of coconut shell used $(12.5-10 \mathrm{~mm})$ which was tougher and harder than small sized particles. The bigger size used (10 $\mathrm{mm}$ and above) will result in lower abrasion and higher impact value as compared to smaller $(0-5 \mathrm{~mm})$ and medium size $(5-10 \mathrm{~mm})$. According to R. Abinesh et al. [30] coconut shell concrete can be used as the load factor against failure for reinforcement ratios for flexural strength is up to $3.14 \%$. Therefore, it will simultaneously solve environmental problems. In another study carried out by Shraddha et al. [31], flexural strength decreases as the content of coconut shell inside the concrete increases. The result was consistent with the ACI-1985 predicted results. Apart from that, Vishwas et al. [32] showed that the flexural behaviour of coconut shell concrete is similar to all other lightweight concrete. All concrete showed typical failure in flexural strength as vertical cracks appeared during pure bending tests.

\subsubsection{Water Absorption}

The water absorption capacity is a measure of the porosity of an aggregate. According to Olan et al. [26] water absorption for coconut shell concrete was found to be at $6.17 \%$. These low values show that coconut shells absorb very little amount of water during the mixing process. Besides that, Anju et. al [33] found that $6.42 \%$ of water absorption rate was obtained for concrete grade M25 with the addition of coconut shell in it. The size used was the same as the aggregate that was replaced. In contrast, Kakade et al. [34] found that the water absorption of coconut shell concrete was found to be at $24 \%$. To prevent the coconut shell from absorbing more water, the coconut shells were soaked for 24 hours in water and were in a surface saturated dry condition during mixing to prevent absorption of mixing water. Besides Kakade et al. [34], Shaikh et al. [35] also found that the water absorption of coconut shell concrete was at $24 \%$. This is due to the higher porosity in its shell structure.

\subsection{Thermal Performance}

For a normal concrete, it is basically can resist at $300{ }^{\circ} \mathrm{C}$ and will start to rapidly lose it strength if being subjected to the hot temperature for a long period of time [36]. Therefore, changes needed to be done so that the concrete can resist at a higher temperature. According to Ganiron et al. [23], coconut shell concrete can resist high temperature conditions. It was subjected to compressive strength to check whether the strength still stayed the same and the result shows that it was still the same at a load capacity of $50.47 \mathrm{kN}$. Apart from hot temperature, Ganiron et al. [23] placed the sample in cold weather to check if coconut shells can resist freezing. It showed that the concrete has a load capacity of $96.69 \mathrm{kN}$. Besides that, Muthusamy et al. [37] stated that coconut shell concrete will reduce in strength after being exposed to high temperatures ranging from $100{ }^{\circ} \mathrm{C}$ to $800^{\circ} \mathrm{C}$. This is due to the expulsion of free water from micro pores and the dehydration of concrete due to high temperature. Another research done by O.M et al. [38] stated that as the percentage of admixture increases, the thermal conductivity and the thermal diffusivity increases. However, the specific heat capacity and the thermal effusivity will decrease. It shows that the admixture or replacement has a serious effect on the cooling load of a building space. Besides that, Zuki et al. [39] had founded that the size of specimen effected the temperature. The larger the size posses greater mass of concrete thus lowering the overall temperature.

\section{Discussion}

Concrete is considered as the major cause of natural material deployment [40-44]. Therefore, many researchers have done studies on agricultural waste to overcome the problem. One of the most famous agricultural waste used is the coconut shell. Based on all the studies that has been reviewed above, many conclusions can be made which include:

\subsection{Workability}

The workability of the coconut shell concrete was superb in comparison to normal concrete. The workability here refers to the true slump that was obtained during the slump test. The workability will decrease as the percentage of replacement or admixture increases. This means that an optimum value of mixing must be obtained in order to obtain better results. The contradiction between Yerramala and Gunasekaran statement is due to the type of coconut shell used. In some countries the properties might differ because of the soil type that affect the result

\subsection{Bulk Density}

The bulk density of concrete that is added with coconut shell will have a value below $2400 \mathrm{~kg} / \mathrm{m}^{3}$. It shows that the concrete will fall under a lightweight concrete class. It is good for construction because lightweight concrete gives more advantages and is easier to handle. 


\subsection{Compressive Strength}

The strength of coconut shell concrete will reduce when the percentage of coconut shell increases. The size that was used for testing the concrete was $20 \mathrm{~mm}$. However, an observation was made where the optimum percentage to be used as an admixture or replacement was below 10 $\%$. The range used will increase the compressive strength and thus makes coconut shells suitable to be used in concrete.

\subsection{Flexural Strength}

The flexural strength of normal concrete and coconut shell concrete is similar. Coconut shells of a bigger size yield better results since there is lower abrasion and higher impact value. However, a conflict in previous studies was observed when other researchers found that the addition of coconut shell to concrete will reduce its flexural strength. Therefore, further research needs to be conducted to evaluate the flexural strength of coconut shell concrete.

\subsection{Water Absorption}

The water absorption of coconut shell concrete shows a lower value that means that the coconut shell absorbs a small amount of water during the mixing process. Other researchers found that the coconut shell absorbs about 24 $\%$ of water. This problem, however, can be countered by soaking the coconut shell in water for about 24 hours. This treatment allows the coconut shell to absorb only a small amount of water during mixing. The high contrast between the researchers shows that it has a different method used by both researchers. The coconut shell that is not treated will absorb more water compared to the threated coconut shell. The method used played an important role during the mixing process.

\subsection{Thermal Performance}

The thermal performance of coconut shell concrete yields a better result than normal concrete. It can withstand a heat of about $800^{\circ} \mathrm{C}$ and only reduces a small amount of compressive strength. It also has some issues in thermal conductivity, thermal diffusivity, specific heat capacity and thermal effusivity. It can be controlled by adding a suitable amount of coconut shells to concrete.

\section{Conclusions}

Based on the review above, the coconut shell is indeed suitable to be used as an admixture or as a replacement for making a concrete cool wall panel. Further research needs to be conducted to find the optimum value and size of particles that need to be used as there is a gap in the literature.

\section{Acknowledgements}

The authors would like to thank Universiti Tun Hussein Onn Malaysia for Grant GPPS U449 and Grant Vot U523.

\section{References}

1 M. A. Mir, P. T. Ghazvinei, N. M. N. Sulaiman, N. E. A. Basri, S. Saheri, N. Z. Mahmood, A. Jahan, R. A. Begum, and N. Aghamohammadi, "Application of TOPSIS and VIKOR improved versions in a multi criteria decision analysis to develop an optimized municipal solid waste management model," J. Environ. Manage, vol. 166, pp. 109115, (2016).

2 M. Abdul Rahim, N. M. Ibrahim, Z. Idris, Z. M. Ghazaly, S. Shahidan, N. L. Rahim, L. A. Sofri, and N. F. Isa, "Properties of Concrete with Different Percentange of the Rice Husk Ash (RHA) as Partial Cement Replacement," Mater. Sci. Forum, vol. 803, pp. 288-293, (2014).

3 M. Osman, M. Nasir, and M. A. Mujeebu, "Assessment of municipal solid waste generation and recyclable materials potential in Kuala Lumpur, Malaysia," Waste Manag., vol. 29, no. 7, pp. 2209-2213, (2009).

4 S. Shahidan, R. Pullin, K. M. Holford, M. B. N, and N. Nor, "Quantitative Evaluation of the Relationship between Tensile Crack and Shear Movement in Concrete beams," Adv. Mater. Res., vol. 626, pp. 355-359, (2013).

5 Y. Zhao, C. Xu, C. Xing, X. Shi, L. M. Matuana, H. Zhou, and X. Ma, "Fabrication and characteristics of cellulose nanofibril films from coconut palm petiole prepared by different mechanical processing," Ind. Crops Prod., vol. 65, pp. 96-101, (2015).

6 A. Rashad, "Cementitious materials and agricultural wastes as natural fi ne aggregate replacement in conventional mortar and concrete," J. Build. Eng., vol. 5, pp. 119-141, (2016)

7 S. A. Kudus, N. M. Bunnori, S. R. Basri, S. Shahidan, M. N. M. Jamil, and N. M. Noor, "An Overview Current Application of Artificial Neural Network in Concrete," Adv. Mater. Res., vol. 626, pp. 372-375, 2012.

8 D. Verma and P. C. Gope, The use of coir/coconut fibers as reinforcements in composites. (2015).

9 R. Kardooni, S. Binti, and F. Binti, "Renewable energy technology acceptance in Peninsular Malaysia," Energy Policy, vol. 88, pp. 1-10, (2016).

10 H. B. Awbi, "Calculation of convective heat transfer coefficients of room surfaces for natural 
convection,” Energy Build., vol. 28, no. 2, pp. 219227, (1998).

11 a. G. Muoz, S. B. Saidman, and J. B. Bessone, "The adaptive simulation of convective heat transfer at internal building surfaces," Build. Environ, vol. 37, no. 8-9, pp. 791-806, (2002).

12 S. Shahidan, N. M. Bunnori, N. Md Nor, and S. R. Basri, "Damage severity evaluation on reinforced concrete beam by means of acoustic emission signal and intensity analysis," in 2011 IEEE Symposium on Industrial Electronics and Applications, (2011), pp. 337-341.

13 K. Gunasekaran, R. Annadurai, and P. S. Kumar, "Long term study on compressive and bond strength of coconut shell aggregate concrete," Constr. Build. Mater, vol. 28, no. 1, pp. 208-215, (2012).

14 D. Y. Osei, C. Engineering, and C. Coast, "Experimental assessment on coconut shells as aggregate in concrete," vol. 2, no. 5, pp. 7-11, (2013).

15 P. S. Kambli and S. R. Mathapati, "Application of Coconut Shell as Coarse Aggregate in Concrete: A Technical Review," vol. 4, no. 3, pp. 498-501, (2014).

16 K. Gunasekaran, "Study on reinforced lightweight coconut shell concrete beam behavior under shear," Mater. Des., vol. 50, pp. 293-301, Sep. (2013).

17 A. Yerramala, "Properties of Concrete with Coconut Shells as Aggregate Replacement," vol. 1, no. 6 , pp.21-31, (2012).

18 M. M. Rahman and K. Kadirgama, "Investigate the Combination of Coconut Shell and Grained," Test, no. October, pp. 49-58, (2009).

19 S. P. G. Akshay S. Shelke, Kalyani R. Ninghot, Pooja P. Kunjekar, "Coconut Shell as Partial Replacement of Coarse Aggregate in Concrete," vol. 5, no. 3, pp. 211-214, (2014).

20 M. Kaur and M. Kaur, "A review on utilization of coconut shell as coarse aggregates in mass concrete," Int. J. Appl. Eng. Res., vol. 7, no. 11 SUPPL., pp. 2063-2065, (2012).

21 I. Ahmed and N. Munigal, "Study on Strength Characteristics of Concrete with Partial Replacement of Cement with Flyash and Coarse Aggregate with Coconut Shell," vol. 1, no. 12, pp. 417-425, (2015)

22 P. Shafigh, H. Bin Mahmud, M. Z. Jumaat, and M. Zargar, "Agricultural wastes as aggregate in concrete mixtures - A review," Constr. Build. Mater., vol. 53, pp. 110-117, (2014).

23 T. U. Ganiron, "Sustainable management of waste coconut shells as aggregates in concrete mixture," J. Eng. Sci. Technol. Rev., vol. 6, no. 5, pp. 7-14, (2013).

24 K. Gunasekaran, P. S. Kumar, and M. Lakshmipathy, "Mechanical and bond properties of coconut shell concrete," Constr. Build. Mater., vol. 25, no. 1, pp. 92-98, (2011).

25 N. Kumar, "Strength Properties of Coconut Shell as Coarse Aggregate In Concrete," (2012).

26 E. A. Olanipekun, K. O. Olusola, and O. Ata, “A comparative study of concrete properties using coconut shell and palm kernel shell as coarse aggregates," Build. Environ., vol. 41, no. 3, pp. 297-301, (2006).

27 B. Rajeevan and K. M. Shamjith, "A Study on the Utilization of Coconut Shell as Coarse Aggregate in Concrete,” Int. J. Eng. Res. Technol., vol. 4, no. 07, pp. 77-80, (2015).

28 D. Ahlawat and L. G. Kalurkar, "Coconut Shell as Partial Replacement of Coarse Aggregate in Concrete," IOSR J. Mech. Civ. Eng., vol. 2014, pp. 61-64, (2014).

29 A. Jaya Prithika and S. K. Sekar, "Mechanical and fracture characteristics of Eco-friendly concrete produced using coconut shell, ground granulated blast furnace slag and manufactured sand," Constr. Build. Mater., vol. 103, pp. 1-7, (2016).

30 A. R and G. K, "Study On Flexural Behavior of Steel-Coconut Shell Concrete - Steel Sandwich Beam using Quarry Dust," vol. 1, no. 11, pp. 433439, (2015).

31 D. Shraddha, F. Hitali, D. Pradeep, and S. Varpe, "Sustainable Concrete by Partially Replacing Coarse Aggregate Using Coconut Shell," J. Today's Ideas - Tomorrow's Technol., vol. 2, no. 1, pp. 4154, (2014).

32 S. kumar B. G. Vishwas P. Kukarni, "Comparative Study on Coconut Shell Aggregate with Conventional Concrete," Int. J. Eng. Innov. Technol., vol. 2, no. 12, pp. 67-70, (2013).

33 Anju Mary Ealias, Rajeena A P, Sivadutt S, Asst. Prof. Life John, and and Asst. Prof. Anju Paul, "Improvement of Strength of Concrete with Partial Replacement Of Course Aggregate With Coconut Shell and Coir Fibres," IOSR J. Mech. Civ. Eng. , vol. 11, no. 3, pp. 16-24, (2014).

34 S. A. Kakade and A. W. Dhawale, "Light Weight Aggregate Concrete By Using Coconut Shell," Int. J. Tech. Res. Appl., vol. 3, no. 3, pp. 127-129, (2015).

35 A. S. Shaikh, S. B. Thorat, R. V Unde, P. S. Shirse, A. S. Shaikh, C. Engineering, and A. Polytechnic, "Advance Concrete-Aggregate replaced by Coconut Shell," (2015).

36 S. Shahidan, S. Salwa, M. Zuki, C. K. Keong, and J. Jayaprakash, "Repaired of Fire-Damaged ConcreteFilled Double Skin Steel Tubular (CFDST) Columns With Fiber Reinforced Polymer (FRP)," ARPN J. Eng. Appl. Sci., vol. 11, no. 6, pp. 3718 3725, (2016).

37 S. Muthusamy and P. Kolandasamy, "Samozbijajui lagani beton na visokim temperaturama," Gradjevinar, vol. 67, no. 4, pp. 329-338, (2015).

38 K. O.M, O. E.C, and S. O.J, "1St International Conference on Heat Transfer, Fluid Mechanics and Thermodynamics," Exp. Therm. Fluid Sci., vol. 23, no. 3-4, pp. I-V, (2000).

39 N. Md Nor, N. Muhamad Bunnori, A. Ibrahim, S. Shahidan, and S. N. M. Saliah, "An investigation on acoustic wave velocity of reinforced concrete beam in-plane source," in Proceedings - 2011 IEEE 7th 
International Colloquium on Signal Processing and Its Applications, CSPA 2011, 2011, pp. 19-22

40 S. Shahidan, H. B. Koh, A. M. S. Alansi, and L. Y. Loon, "Strength Development and Water Permeability of Engineered Biomass Aggregate pervious Concrete," vol. 7, pp. 2-7.

41 S. Shahidan, I. Isham, and N. Jamaluddin, "A Review on Waste Minimization by Adopting in Self Compacting Concrete," MATEC Web Conf., vol. 47, pp. 1-7, (2016).

42 N. Salleh, A. R. Mohd Sam, and J. Mohd Yatim, "Flexural Behavior of GFRP RC Beam Strengthened with Carbon Fiber Reinforced Polymer (CFRP) Plate: Cracking Behavior," Appl. Mech. Mater., vol. 752-753, pp. 610-616, 2015.

43 M. H. Wan Ibrahim, N. Jamaludin, J. M. Irwan, P. J. Ramadhansyah, and a. Suraya Hani, "Compressive and Flexural Strength of Foamed Concrete Containing Polyolefin Fibers," Adv. Mater. Res., vol. 911, no. October, pp. 489-493, 2014.

44 R. P. Jaya, B. H. Abu Bakar, M. A. M. Johari, M. H. W. Ibrahim, M. R. Hainin, and D. S. Jayanti, "Strength and microstructure analysis of concrete containing rice husk ash under seawater attack by wetting and drying cycles," Adv. Cem. Res., vol. 26, no. MAY, pp. 145-154, 2014. 